\title{
Urinary incontinence in the prediction of falls in hospitalized elderly"
}

\author{
INCONTINÊNCIA URINÁRIA NA PREDIÇÃO DE QUEDAS EM IDOSOS HOSPITALIZADOS
}

INCONTINENCIA URINARIA EN LA PREDICCIÓN DE CAÍDAS EN ANCIANOS HOSPITALIZADOS

\author{
Hellen Cristina de Almeida Abreu ${ }^{1}$, Annelita Almeida Oliveira Reiners ${ }^{2}$, Rosemeiry Capriata de \\ Souza Azevedo², Ageo Mário Cândido da Silva ${ }^{3}$, Débora Regina de Oliveira Moura Abreu ${ }^{4}$
}

\begin{abstract}
Objective: Analyzing the effect of urinary incontinence as a predictor of the incidence of falls among hospitalized elderly. Method: Concurrent cohort study where 221 elderly inpatients were followed from the date of admission until discharge, death or fall. The Kaplan-Meier methods, the incidence density and the Cox regression model were used for the survival analysis and the assessment of the association between the exposure variable and the other variables. Results: Urinary incontinence was a strong predictor of falls in the surveyed elderly, and was associated with shorter time until the occurrence of event. Urinary incontinence, concomitant with gait and balance dysfunction and use of antipsychotics was associated with falls. Conclusion: Measures to prevent the risk of falls specific to hospitalized elderly patients who have urinary incontinence are necessary.
\end{abstract}

\section{RESUMO}

Objetivo: Analisar o efeito da incontinência urinária como preditora da incidência de quedas entre idosos hospitalizados. Método: Estudo de coorte concorrente onde foram acompanhados 221 idosos internados, desde a data da admissão hospitalar até a alta, óbito ou queda. A análise de sobrevivência e a verificação da associação entre a variável de exposição e as demais variáveis foram realizadas pelos métodos de Kaplan-Meier, densidade de incidência e o modelo de regressão de Cox. Resultados: $\mathrm{A}$ incontinência urinária foi um forte preditor de quedas nos idosos pesquisados e esteve associada ao menor tempo de ocorrência do evento. A incontinência urinária, concomitante à disfunção de equilíbrio e marcha e uso de antipsicóticos foram associadas às quedas. Conclusão: São necessárias medidas de prevenção de risco de quedas específicas aos pacientes idosos hospitalizados que apresentam incontinência urinária.

\section{RESUMEN}

Objetivo: Analizar el efecto de la incontinencia urinaria como pronosticadora de la incidencia de caídas entre ancianos hospitalizados. Método: Estudio de cohorte concurrente en el que se acompañaron a 221 personas mayores en estancia hospitalaria, desde la fecha del ingreso hasta el alta, defunción o caída. El análisis de supervivencia y la verificación de la asociación entre la variable de exposición y las demás variables se llevaron a cabo por los métodos de Kaplan-Meier, densidad de incidencia y el modelo de regresión de Cox. Resultados: La incontinencia urinaria fue un fuerte pronosticador de caídas en los añosos investigados y estuvo asociada con el menor tiempo de ocurrencia del evento. La incontinencia urinaria, concomitante con la disfunción de equilibrio y marcha y el uso de antipsicóticos, estuvieron asociadas con las caídas. Conclusión: Son necesarias medidas de prevención de riesgo de caídas específicas a los pacientes añosos hospitalizados que presentan incontinencia urinaria.

\section{DESCRIPTORES \\ Anciano \\ Pacientes internos \\ Incontinencia urinaria \\ Accidentes por caídas \\ Análisis de supervivencia \\ Enfermería geriátrica}

\author{
DESCRITORES \\ Pacientes internados \\ Acidentes por quedas \\ Análise de sobrevida \\ Enfermagem geriátrica
}

Geriatric nursing 


\section{INTRODUCTION}

Urinary incontinence (UI) and the accident by falls are considered two of the most important and recurrent geriatric syndromes due to the magnitude of its occurrence and its consequences ${ }^{(1-2)}$. They can affect the elderly in all age groups, especially those of advanced age ${ }^{(3-5)}$.

It is estimated that one-third of the elderly living in the community and about half of hospitalized or living in longstay institutions present $\mathrm{UI}{ }^{(5)}$. Between $30 \%$ and $50 \%$ of hospitalized elderly and residing in long-stay institutions suffered falls once in a lifetime ${ }^{(6-7)}$.

Both syndromes are related to the need for institutional care, increased hospitalization time and also, the prevalence of anxiety and depression ${ }^{(5,8-9)}$.

Studies have reported associations between UI and falls $s^{(9-11)}$. Most of them were carried out with elderly residing in the community, with cross-sectional epidemiological designs and showed that this condition is often associated with the occurrence of falls in this population, especially the urge incontinency ${ }^{(5,9)}$. However, to date, longitudinal studies with hospitalized elderly identifying $\mathrm{UI}$ as a risk factor associated with falls are scarce ${ }^{(12-13)}$.

The prevention of falls among the elderly in hospitals is an imperative action in these institutions. In addition to suffering more falls, the elderly with UI have longer hospital stays and higher use of health resources ${ }^{(12-14)}$. However, additional studies on the influence of $\mathrm{UI}$ on the occurrence of falls among the elderly with incontinence are necessary in order that specific prevention strategies are adopted for these patients.

Thus, this study aimed at analyzing the effect of urinary incontinence as a predictor of the incidence of falls among elderly patients in hospitals.

\section{METHOD}

This is a concurrent, prospective cohort study, which followed 221 elderly patients admitted to medical wards in three large general hospitals, under the Unified Health System (SUS) of Cuiabá, Mato Grosso, in the period from March to August 2013.

This study included people of both genders, aged 60 years or older, hospitalized in the internal medicine division of the aforementioned hospitals. Three elderly patients with compromised mental capacity, evaluated with the Mini-Mental State Examination (MMSE) ${ }^{(10)}$ and without companions able to respond to the survey questionnaire were excluded.

The exposure variable, urinary incontinence (UI), was obtained by questioning the involuntary loss of urine. The following sociodemographic variables were included in the analysis: gender (female and male), age (categorized in years, subsequently re-categorized into three age groups [60 - 69 years, $70-79$ years and 80 years or older]), education ( $<3$ years and 4 years or more), income of the elderly in minimum wages (SM) (less than 1 and 2 or more SM). The presence of some comorbidities in the medical records were considered as variables on the health of the elderly, namely: hypertension, diabetes, osteoporosis and stroke. The presence of gait disturbance assessed by applying the Tinetti gait and balance examination was also includ$\mathrm{ed}^{(15)}$, as well as the use of antihypertensive drugs, hypoglycemic agents, anxiolytics, antipsychotics and anticonvulsants.

The analysis of the time until the occurrence of falls and the identification of the association between the exposure variable and the other predictive variables was done using the Kaplan-Meier method, which estimates the function and survival curve ${ }^{(16)}$. The date of admission to hospital was used as time zero. Initially, were assessed the ratios of incidence rate (Hazard Ratio - HR) of exposed and unexposed, having as explanatory variables the presence or absence of $\mathrm{UI}$ and other variables, and as the response variable, the occurrence of falls or not. The method used was the incidence density, in which the number of people / time is calculated by estimating the time of observation of each individual from the date of admission until the date of occurrence of the event (fall) or discharge / death (censoring). For the final analysis was used the Cox regression model, in which the $p$-value of 0.20 was considered for entry of predictive variables in the initial model, and for the variable remaining in the final model was considered the 0.05 level of significance. Analyses were done using the Statistical Package for Social Sciences 18.0 (SPSS).

The study was approved by the Ethics Committee in Research of the Hospital Universitário Julio Muller - under protocol number 206.880/2013 of the Plataforma Brasil.

\section{RESULTS}

Among the 221 surveyed seniors, the majority were male $(n=117,52.9 \%)$, aged $70-79$ years $(n=85,38.5 \%)$, mean age of 73.9 years ( \pm 8.6 years), with less than three years of study ( $n=156,70.6 \%$ ) and income of less than one minimum wage $(n=191,86.5 \%)$.

The results of the survival analysis (life table) are shown in table 1 and figure 1 . The overall survival obtained by the Kaplan-Meier method was $42.0 \%$ at the end of the study period, while between 20 and 39 days the estimated survival was $70.0 \%$. 
Table 1 - Life table for the time until occurrence of falls in hospitalized elderly - Cuiabá, MT, 2013

\begin{tabular}{|c|c|c|c|c|c|c|c|c|}
\hline \multirow{2}{*}{$\begin{array}{c}\text { Time } \\
\text { (in days) }\end{array}$} & Individuals & $\begin{array}{c}\text { Censored } \\
\text { events }\end{array}$ & $\begin{array}{c}\text { Exposure to } \\
\text { risk }\end{array}$ & $\begin{array}{c}\text { Occurrence } \\
\text { of event }\end{array}$ & \multirow{2}{*}{$\begin{array}{c}\text { Occurrence } \\
\text { of event } \\
\text { (proportion) }\end{array}$} & \multirow{2}{*}{$\underset{\text { (proportion) }}{\text { Survival }}$} & \multirow{2}{*}{$\begin{array}{l}\text { Cumulative } \\
\text { survival }\end{array}$} & \multirow{2}{*}{$\begin{array}{c}\text { Standard } \\
\text { error of } \\
\text { survival }\end{array}$} \\
\hline & $\mathbf{n}$ & $\mathbf{n}$ & $\mathbf{n}$ & $\mathbf{N}$ & & & & \\
\hline 0 to 19 & 221 & 158 & 142 & 32 & 0.23 & 0.77 & 0.77 & 0.04 \\
\hline 20 to 39 & 31 & 20 & 21 & 2 & 0.10 & 0.90 & 0.70 & 0.06 \\
\hline 40 to 59 & 9 & 6 & 6 & 0 & 0.00 & 1.00 & 0.70 & 0.06 \\
\hline 60 to 79 & 3 & 1 & 2 & 1 & 0.50 & 0.50 & 0.42 & 0.22 \\
\hline 80 and more & 1 & 1 & 1 & 0 & 0.00 & 1.00 & 0.42 & 0.22 \\
\hline
\end{tabular}

Note: $(\mathrm{N}=221)$

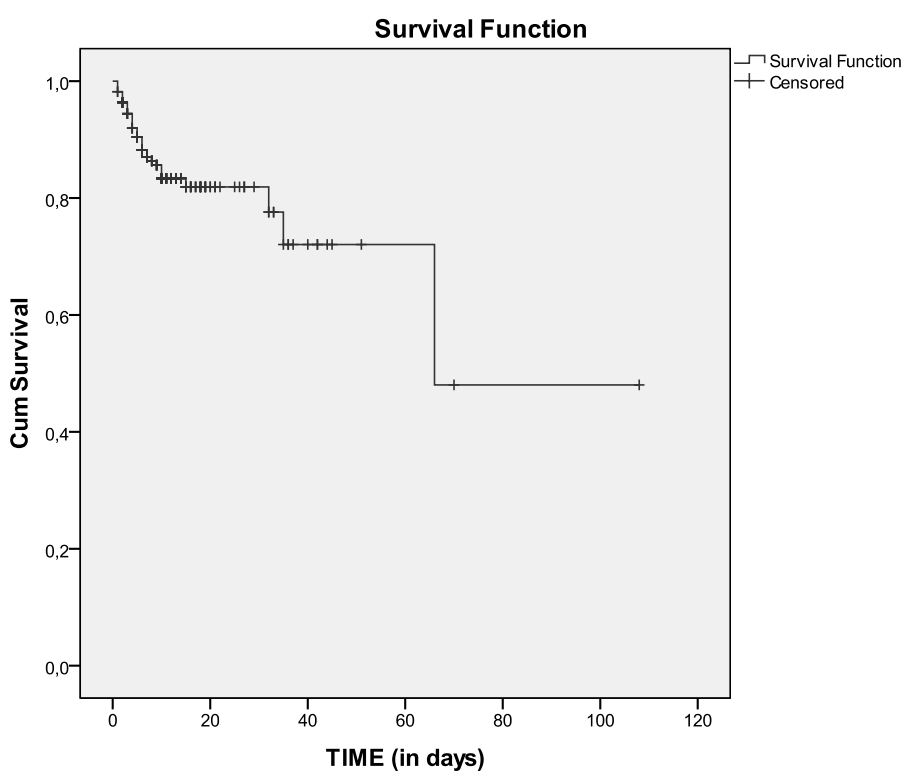

Figure 1 - Survival function of hospitalized elderly until the occurrence of falls obtained by the method of Kaplan-Meier-Cuiabá, MT, 2013.

The variables associated with falls were the following: pres- $\quad 2.32-12.09)$, use of hypoglycemic agents (RR=2.22 Cl 95\%: ence of urinary incontinence ( $R R=6.80 ; \mathrm{Cl} 95 \%$ : 3.38-13.64), $\quad 1.12-4.40)$, use of anxiolytics (RR=4.36 Cl 95\% 1.84-10.30) and presence of gait and balance dysfunction ( $R R=5.30$; $\mathrm{Cl} 95 \%$ : use of antipsychotics ( $R R=3.51 \mathrm{Cl} 95 \%$ : 1.38-8.89) (Table 2).

Table 2 - Distribution of hospitalized elderly patients who suffered falls by incidence density of hospital stay, according to the variables of health conditions - Cuiabá, MT, 2013

\begin{tabular}{|c|c|c|c|c|c|c|}
\hline Variables & Fall & People-time & Incidence(*) & $\mathbf{R R}$ & (CI 95\%) & $p$ value \\
\hline \multicolumn{7}{|c|}{ Urinary incontinence } \\
\hline No & 24 & 2609 & 9.20 & 1.00 & & \\
\hline Yes & 11 & 176 & 62.50 & 6.80 & $(3.38-13.64)$ & $<0.001$ \\
\hline \multicolumn{7}{|l|}{ Age range (years) } \\
\hline$\leq 69$ & 16 & 82 & 19.5 & 1.00 & & \\
\hline$\geq 70$ & 19 & 139 & 13.7 & 1.42 & $(0.78-2.62)$ & 0.251 \\
\hline \multicolumn{7}{|l|}{ Hypertension } \\
\hline No & 2 & 441 & 4.53 & 1.00 & & \\
\hline Yes & 33 & 2339 & 14.11 & 3.11 & $(0.75-12.92)$ & $0.066^{*}$ \\
\hline \multicolumn{7}{|l|}{ Diabetes } \\
\hline No & 19 & 1914 & 9.95 & 1.00 & & \\
\hline Yes & 16 & 866 & 18.47 & 1.86 & $(0.96-3.60)$ & 0.061 \\
\hline \multicolumn{7}{|l|}{ Balance/gait } \\
\hline No dysfunction & 7 & 1584 & 4.42 & 1.00 & & \\
\hline With dysfunction & 28 & 1196 & 23.41 & 5.30 & $(2.32-12.09)$ & $<0.001$ \\
\hline \multicolumn{7}{|l|}{ Antihypertensive } \\
\hline No & 2 & 397 & 5.04 & 1.00 & & \\
\hline Yes & 33 & 2383 & 13.85 & 2.74 & $(0.66-11.41)$ & $0.067 *$ \\
\hline
\end{tabular}


Continuation...

\begin{tabular}{|c|c|c|c|c|c|c|}
\hline Variables & Fall & People-time & Incidence(*) & RR & (CI 95\%) & p value \\
\hline \multicolumn{7}{|c|}{ Hypoglycemic agents } \\
\hline No & 13 & 1579 & 8.23 & 1.00 & & \\
\hline Yes & 22 & 1201 & 18.32 & 2.22 & $(1.12-4.40)$ & 0.018 \\
\hline \multicolumn{7}{|l|}{ Anxiolytics } \\
\hline No & 29 & 2654 & 10.93 & 1.00 & & \\
\hline Yes & 6 & 126 & 47.62 & 4.36 & $(1.84-10.30)$ & $<0.001$ \\
\hline \multicolumn{7}{|c|}{ Antipsychotics } \\
\hline No & 30 & 2654 & 11.30 & 1.00 & & \\
\hline Yes & 5 & 126 & 39.68 & 3.51 & $(1.38-8.89)$ & $0.019 *$ \\
\hline \multicolumn{7}{|c|}{ Anticonvulsants } \\
\hline No & 32 & 2700 & 11.85 & 1.00 & & \\
\hline Yes & 2 & 80 & 37.50 & 3.16 & $(0.99-10.12)$ & $0.077 *$ \\
\hline
\end{tabular}

RR: relative risk; $\mathrm{Cl} 95 \%$ : confidence interval for the proportion of $95 \%$.

$\left.{ }^{*}\right)$ : per 1000 people-time

* Fisher's test

The variables that remained in the final model of Cox were

presence of gait and balance dysfunction ( $R R=4.56 ;(1.81-11.45))$ the presence of urinary incontinence $(R R=5.46 ;(2.48-12.01))$,

and use of antipsychotics (RR= 3.62; (1.33-7.04)) (Table 3).

Table 3 - Regression of proportional risks of Cox for incidence of falls in hospitalized elderly - Cuiabá, MT, 2013

\begin{tabular}{lccc}
\hline Variables & RR & (CI 95\%) & p value \\
\hline Age range (years) & & & \\
$\leq 69$ & 1.00 & $(0.71-3.19)$ & 0.274 \\
$\geq 70$ & 1.51 & & \\
Urinary incontinence & & & \\
No & 1.00 & $(2.48-12.01)$ & \\
Yes & 5.46 & & 0.001 \\
Balance/gait & 1.00 & $(1.81-11.45)$ & 0.001 \\
With dysfunction & 4.56 & & 0.049 \\
Without dysfunction & & & \\
Use of antipsychotics & 1.00 & $(1.33-7.04)$ & \\
No & 3.62 & & \\
Yes &
\end{tabular}

RR: relative risk; $\mathrm{Cl} 95 \%$ : confidence interval for the proportion of $95 \%$.

In Figure 2, the Kaplan-Meier curve indicates the influence of urinary incontinence on the survival of hospitalized elderly. Compared with individuals without
UI, patients with incontinence had significantly shorter survival, i.e., were more likely to suffer falls in the first days of hospitalization.

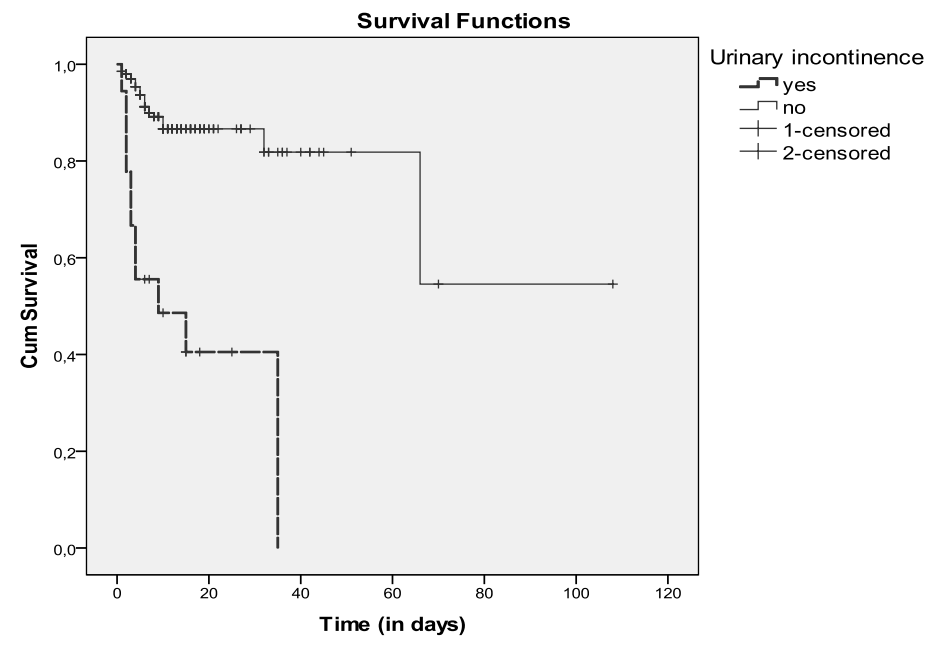

Figure 2 - Survival function (Kaplan-Meier) of hospitalized elderly patients with urinary incontinence - Cuiabá, MT, 2013. 


\section{DISCUSSION}

In this study, the UI was a strong predictor of falls in the studied population, similar to that found in existing longitudinal studies ${ }^{(12-13)}$. Another relevant finding was that incontinent patients suffered falls with shorter hospital stay than those without UI, reinforcing the assumption that this condition influences the occurrence of falls in hospitalized elderly. One explanation is the more frequent need to urinate of the elderly, as well as their inability to postpone urination, forcing them to go to the bathroom more often than expected hence, exposing them to increased risk of falls ${ }^{(17)}$. In a study with 77 hospitalized adults with UI, it was found that $85.2 \%$ of them woke up to go to the bathroom ${ }^{(18)}$. This task can be even more difficult by the concomitant presence of other risk factors such as comorbidities and poor ambient lighting ${ }^{(19)}$. Allied to this, it must be considered that especially at nighttime, the elderly tend not to call the nurse to help them with activities they believe to be able to perform ${ }^{(20-21)}$.

In this study, the UI and the gait and balance dysfunction were independently associated with falls, and remained in the final model. Similar results were found in one of the existing longitudinal studies ${ }^{(12)}$, in which the balance deficit was one of the predictor factors for falls in hospitalized elderly.

The deficiencies in the visual, vestibular and somatosensory systems occur with aging and can lead to difficulties in gait and balance. In the elderly, this dysfunction concomitantly with UI may result in falls due to the combination of postural instability, the urgent need to go to the bathroom and the concern about not urinating on the clothes $^{(20)}$.

The use of antipsychotics was associated with the risk of falls. Previous studies demonstrated the use of antipsychotics as a risk factor for falls in hospitalized elderly ${ }^{(22-23)}$. A possible explanation is that these drugs lead to higher rates of adverse effects, among them, incontinence and / or urinary tract infections, and possible changes in gait and balance, which, combined, can lead to greater incidence of falls ${ }^{(24-25)}$.

In this study, survival was not affected by the age of the elderly. This finding is different from that found in other studies ${ }^{(12-13)}$. However, it was chosen to maintain the age variable in the Cox regression, which allowed a better fit in the final model.

\section{REFERENCES}

1. Santos CRSS, Santos VLCGS. Epidemiologia das incontinências urinária e anal combinadas. Acta Paul Enferm. 2009;22(3):328-30.
Concurrent prospective cohort studies, such as the present research have greater validity than other observational studies, because they allow the assessment of the outcome at the time it occurred, not being susceptible to bias of memory and information, among other common limitations of nonconcurrent studies. Moreover, taking into account the proposed objective, the survival analysis has greater advantage than other methods of statistical analysis, since it uses the estimation of the incidence density and comparison rates through people-time, and not prevalence data. However, because this is an observational method, the presence of other possible biases cannot be excluded.

Finally, the results of this study deepen the knowledge about two of the major syndromes that affect the elderly, urinary incontinence and falls, and future studies should consider them. The clinical implication of these findings lies in the need to implement multidisciplinary and intersectoral interventions that help to reduce the risk of falls in elderly incontinent patients. There are nursing interventions based on evidence that have contributed to this reduction $^{(26-27)}$. These measures include identification of patients with UI, specific treatment and care, as well as protective measures to increase the safety of these patients (bars on beds, protection bars and adequate lighting in bedrooms and bathrooms, bedpans and urinals next to the bed).

There is also the need for implementing educational measures with patients and caregivers on the risk of falls and the ways of preventing them. Generally, patients and caregivers have no knowledge about the factors that lead to greater incidence of falls in hospitals. People with more knowledge about their health situation and the ways of dealing with it are more likely to adopt appropriate health behaviors and prevent problems. Studies on educational interventions for preventing falls in hospitals have been carried out and show evidence that, to some extent, such interventions contribute to the reduction of the event ${ }^{(28-29)}$.

\section{CONCLUSION}

The UI was a strong predictor of falls in the surveyed elderly and associated with shorter time until occurrence of the event. This study also demonstrated that UI, concomitant with gait and balance dysfunction and antipsychotics were associated with falls. These results suggest that measures for preventing risk of specific falls should be adopted with hospitalized elderly patients who have urinary incontinence.
2. Edwards R, Martin FC, Grant R, Lowe D, Potter J, Husk J, et al. Is urinary continence considered in the assessment of older people after a fall in England and Wales? Cross-sectional clinical audit results. Maturitas. 2011;69(2):179-83.
Urinary incontinence in the prediction of falls in hospitalized elderly* Abreu HCA, Reiners AAO, Azevedo RCS, Silva AMC, Abreu DROM 
3. Du Moulin MF, Hamers JP, Ambergen AW, Janssen MA, Halfens RJ. Prevalence of urinary incontinence among community-dwelling adults receiving home care. Res Nurs Health. 2008;31(6):604-12.

4. Liapis A, Bakas P, Liapi S, Sioutis D, Creatsas G. Epidemiology of female urinary incontinence in the Greek population: EURIG study. Int Urogynecol J. 2010;21(2):217-22.

5. Haylen BT, Ridder D, Freeman RM, Swift SE, Berghmans B, Lee J, et al. An International Urogynecological Association (IUGA)/ International Continence Society (ICS) joint report on the terminology for female pelvic floor dysfunction. Neurourol Urodyn. 2010;29(1):4-20.

6. Stevens JA, Corso PS, Finkelstein EA, Miller TR. The costs of fatal and non-fatal falls among older adults. Inj Prev. 2006;12(5):290-5.

7. Ferreira DCO, Yoshitome AY. Prevalência e características das quedas de idosos institucionalizados. Rev Bras Enferm. 2010;63(6):991-7.

8. Offermans MPW, Du Moulin MFMT, Hamers JPH, Dassen T, Halfens RJ. Prevalence of urinary incontinence and associated risk factors in nursing home residents: a systematic review. Neurourol Urodyn. 2009;28(4):288-94.

9. Foley AL, Loharuka S, Barrett JA, Mathews R, Williams K, McGrother CW, et al. Association between the geriatric giants of urinary incontinence and falls in older people using data from the Leicestershire MRC Incontinence Study. Age Ageing. 2012;41(1):35-40.

10. Dellaroza MSG, Pimenta CAM, Lebrão ML, Duarte YAO, Braga PE. Associação entre dor crônica e autorrelato de quedas: estudo populacional - SABE. Cad Saúde Pública. 2014;30(3):522-32.

11. Hunter KF, Voaklander D, Hsu ZY, Hsu ZY. Lower urinary tract symptoms and falls risk among older women receiving home support: a prospective cohort study. BMC Geriatr. 2013;13:46.

12. Corsinovi L, Bo M, Ricauda Aimonino N, Marinello R, Gariglio $F$, Marchetto $C$, et al. Predictors of falls and hospitalization out comes in elderly patients admitted to an acute geriatric unit. Arch Gerontol Geriatr. 2009;49(1):142-5.

13. Tanaka B, Sakuma M, Ohtani M, Toshiro J, Matsumura T, Morimoto $\mathrm{T}$, et al. Incidence and risk factors of hospital falls on long-term care wards in Japan. J Eval Clin Pract. 2012;18(3):572-7.

14. Härlein J, Halfens RJ, Dassen T, Lahmann NA. Falls in older hospital inpatients and the effect of cognitive impairment: a secondary analysis of prevalence studies. J Clin Nurs. 2011;20(1-2):175-83.

15. Tinetti ME. Performace- oriented assessment of mobility problems in elderly patients. J Am Geriatr Soc. 1986;34(2):119-26.
16. Klein JP, Moeschberger ML. Survival analysis: techniques for censored and truncated data. New York: Springer-Verlag; 1997.

17. Chiarelli PE, Mackenzie LA, Osmotherly PG. Urinary incontinence is associated with an increase in falls: a systematic review. Aust J Physiother. 2009;55(2):89-95.

18. Silva APM, Santos VLCG. Prevalência da incontinência urinária em adultos e idosos hospitalizados. Rev Esc Enferm USP [Internet]. 2005[citado 2014 fev. 04];39(1):36-45. Disponível em: http://www.scielo.br/pdf/reeusp/v39n1/ a05v39n1.pdf

19. World Health Organization. Injuries and violence: the facts. Geneva: WHO; 2010.

20. Morris V, Hunter KF, Wagg A. Urinary incontinence and falls: a link ripe for interventions. Geriatr Med. 2011;41(6):333-6.

21. Paiva MC, Paiva SA, Berti HW, Campana AO. Characterization of patient falls according to the notification in adverse event reports. Rev Esc Enferm USP [Internet]. 2010 [cited 2014 Feb 04]; 44(1):134-8. Available from: http://www.scielo.br/pdf/ reeusp/v44n1/en_a19v44n1.pdf

22. Rhalimi M, Helou R, Jaecker P. Medication use and increased risk of falls in hospitalized elderly patients: a retrospective case-control study. Drugs Aging. 2009; 26(10):847-52.

23. Shuto $\mathrm{H}$, Imakyure $\mathrm{O}$, Matsumoto J, Egawa T, Jiang $\mathrm{Y}$, Hirakawa $\mathrm{M}$, et al. Medication use as a risk factor for inpatient falls in an acute care hospital: a case-crossover study. $\mathrm{Br} J$ Clin Pharmacol. 2010;69(5):535-42.

24. Ramos MG, Rocha FL. Eficácia e segurança dos antipsicóticos atípicos nas demências: uma revisão sistemática. J Bras Psiquiatr. 2006;55(3):218-24.

25. Messinger-Rapport B, Dumas L. Falls in the nursing home: a collaborative approach. Nurs Clin North Am. 2009;44(2):187-95.

26. Wenger NS, Roth CP, Shekelle PG, Young RT, Solomon DH, Kamberg CJ, et al. A practice-based intervention to improve primary care for falls, urinary incontinence, and dementia. J Am Geriatr Soc. 2009;57(3):547-55.

27. Klay M, Marfyak K. Use of a continence nurse specialist in an extended care facility. Urol Nurs. 2005;25(2):101-2, 107-8.

28. Haines TP, Hill AM, Hill KD, McPhail S, Oliver D, Brauer S, et al. Patient education to prevent falls among older hospital inpatients: a randomized controlled trial. Arch Intern Med. 2011;171(6):516-24.

29. Hill AM, Etherton-Beer C, Haines TP. Tailored education for older patients to facilitate engagement in falls prevention strategies after hospital discharge: a pilot randomized controlled trial. Plos One. 2013;8(5):e63450. 